\title{
Is surgery necessary to confirm diagnosis of right-sided diverticulitis in spite of relevant clinical and radiological findings?
}

\author{
Erkan Yardımcı, M.D., ${ }^{1}$ Mustafa Hasbahçeci, M.D., ${ }^{1}$ Ufuk Oğuz İdiz, M.D., ${ }^{1}$ \\ Musa Atay, M.D., ${ }^{2}$ Hüseyin Akbulut, M.D. ${ }^{1}$
}

${ }^{1}$ Department of General Surgery, Bezmialem Vakıf University Faculty of Medicine, İstanbul-Turkey

${ }^{2}$ Department of Radiology, Bezmialem Vakıf University Faculty of Medicine, İstanbul-Turkey

\begin{abstract}
BACKGROUND: Diverticulosis of the right colon is an uncommon entity. Aim of the present study was to report outcome in patients with right-sided diverticulitis diagnosed using computed tomography (CT) and treated conservatively.

METHODS: Twelve patients with clinical and radiological diagnosis of cecal or right-sided diverticulitis who were treated conservatively between February 2013 and December 2014 were included. Demographic and clinical data were retrospectively analyzed.

RESULTS: Female to male ratio was I:I with mean age of $45.08 \pm 14.4$ years. Mean length of symptom history before admission was $2.08 \pm \mathrm{I} .3$ days. Most common presenting symptom was right lower abdominal pain, seen in $72.7 \%$ of the patients. Abdominal ultrasound alone was performed for 10 patients, and 2 also had abdominal CT. Mean duration of hospitalization was $2.8 \pm 1.5$ days. All patients were successfully treated with medical therapy. There was no recurrence during mean follow-up period of $8.2 \pm 5.6$ months.
\end{abstract}

CONCLUSION: If uncomplicated diverticulitis of the right colon is correctly diagnosed with radiological evaluation, antibiotic therapy and bowel rest should be considered as treatment modality, as there was no recurrence observed in short-term follow-up period and this option presents advantage of avoiding surgical intervention.

Keywords: Antibiotic; cecum; computed tomography; diverticulitis; right colon.

\section{INTRODUCTION}

Right-sided colonic diverticulitis (RCD), is an uncommon entity in Western countries, constituting between $1 \%$ and $3.6 \%$ of all colonic diverticular diseases; however, diverticular disease of the colon is diagnosed in almost one-quarter of the patients who presented at emergency departments with acute abdominal symptoms. ${ }^{[1,2]}$ Differential diagnosis is important to decrease rate of negative laparotomy in patients with acute symptoms caused by diverticular disease of the colon. $\mathrm{RCD}$ is usually accompanied by lower right quadrant or il-

Address for correspondence: Ufuk Oğuz İdiz, M.D.

Şişli Etfal Eğitim ve Araştırma Hastanesi, Genel Cerrahi Kliniği, İstanbul, Turkey

Tel: +90 212 - 3735000 E-mail: oguzidiz@yahoo.com

Qucik Response Code

Ulus Travma Acil Cerrahi Derg

20I7;23(I):6I-65

doi: $10.5505 /$ tjtes. 2016.51460

Copyright 2017

TJTES iac fossa pain, vomiting, nausea, fever, and anorexia. ${ }^{[3]}$ Due to similar presentation to acute appendicitis, misdiagnosis is common. In the past, it was very difficult to distinguish patients with RCD; therefore, intraoperative diagnosis was common and extensive surgical operations were performed. [4,5] Currently, accurate diagnosis of RCD is usually feasible using radiological techniques, such as ultrasound (US) and/or computed tomography (CT). ${ }^{[6]}$

Treatment of RCD has varied from conservative management to extensive surgery, such as right hemicolectomy. ${ }^{[7]}$ Initial reports have indicated that RCD may be treated conservatively as successfully as left-sided diverticulitis. ${ }^{[6]}$ Conservative management of RCD may be an effective treatment modality in cases diagnosed with imaging techniques. Surgical treatment may be necessary for diverticular bleeding unresponsive to conservative management, or recurrent and/or complicated diverticulitis in cases with perforation, abscess formation, intestinal obstruction, or fistula. ${ }^{[2,8]}$ Therefore, treatment of $R C D$ remains a controversial issue. 
The aim of this study was to evaluate RCD patients with regard to clinical presentation, laboratory and imaging findings, and outcomes of conservative management.

\section{MATERIALS AND METHODS}

The Bezmialem Vakif University hospital institutional review board granted approval for retrospective review of patients who were identified using radiology information system (RIS) and hospital information system (HIS) by entering the words "colonic diverticulitis" and "cecal diverticulitis" in keyword search. In addition, reports of imaging methods used (US and $\mathrm{CT}$ ) in these cases during the study period (from February 2013 to December 2014) were retrieved. Among cases with colonic diverticulitis, diagnoses of right-sided diverticulitis with acute presentation were then identified using HIS. Patients who had left-sided diverticulitis mimicking right colonic diverticulitis or who were diagnosed with colon tumor were excluded from the study. Pregnant patients and patients without complete data were also excluded.

Patient age, sex, history, comorbidities, presenting symptoms, laboratory results, and radiological findings were analyzed retrospectively. All patients admitted with right lower quadrant pain mimicking acute appendicitis underwent blood testing to determine white blood cell (WBC) count (upper limit of normal $=10 \times 10^{3} / \mu \mathrm{L}$ ) and C-reactive protein (CRP) level (upper limit of normal $=0.5 \mathrm{mg} / \mathrm{dL}$ ). All patients also underwent US diagnostic imaging, and depending on the discretion of the surgeon, additional CT. If US examination was not diagnostic for pathology of right lower abdominal pain due to characteristics such as obesity, excessive bowel gas, or edematous and incompressible terminal ileum or cecum, the patients underwent CT scanning. Criteria of CT scanning for diagnosis of right-sided diverticulitis included colonic wall thickening and edema, pericolonic fat infiltration, pericolonic abscess, and extraluminal air around the cecum or ascending colon in the presence of diverticula (Figure I). Inflamed diverticulum or phlegmon determined by
US andor CT images determined status of uncomplicated diverticulitis.

Within first 24 hours after admission, attending surgeon decided on appropriateness of conservative management based on clinical and laboratory findings and imaging results. Conservative management included pain control, nothing per mouth except fluids, and intravenous broad-spectrum antibiotics. At discharge, oral antibiotics were given. Patients were re-evaluated at I week and again at I month after discharge.

\section{Statistical Analysis}

Normally distributed continuous variables were expressed as mean \pm standard deviation. Categorical variables were expressed as frequency and percentage of appropriate denominator.

\section{RESULTS}

There were 12 patients included in the study, with mean age of $45.08 \pm 14.4$ years. Female to male ratio was I:I. Mean length of symptom history before hospital admission was $2.08 \pm 1.3$ days. Details of presenting symptoms are provided in Table I. Localized right lower abdominal pain and pain lasting more than 2 days were most common symptoms, seen in $8(72.7 \%)$ and $7(58.3 \%)$ patients, respectively. Of the patients, $66.6 \%$ had elevated WBC count $\left(>10 \times 10^{3} / \mu \mathrm{L}\right)$, with mean of $11.9 \times 10^{3} / \mu \mathrm{L}$ and $91.6 \%$ of the patients had high CRP level $(>0.5 \mathrm{mg} / \mathrm{dL})$, with mean of $7.3 \mathrm{mg} / \mathrm{dL}$. US was performed on all patients; 2 also underwent abdominal CT. CT findings are provided in Table 2.

Mean duration of hospitalization was $2.8 \pm \mathrm{I} .5$ days. All patients were successfully treated with conservative management; there were no complications. Patients had appointment for follow-up in the outpatient clinic I week and I month after discharge. Patients were interviewed over the phone to identify any recurring symptoms or surgical interventions at mean follow-up of $8.2 \pm 5.6$ months, and no recurrence was found.
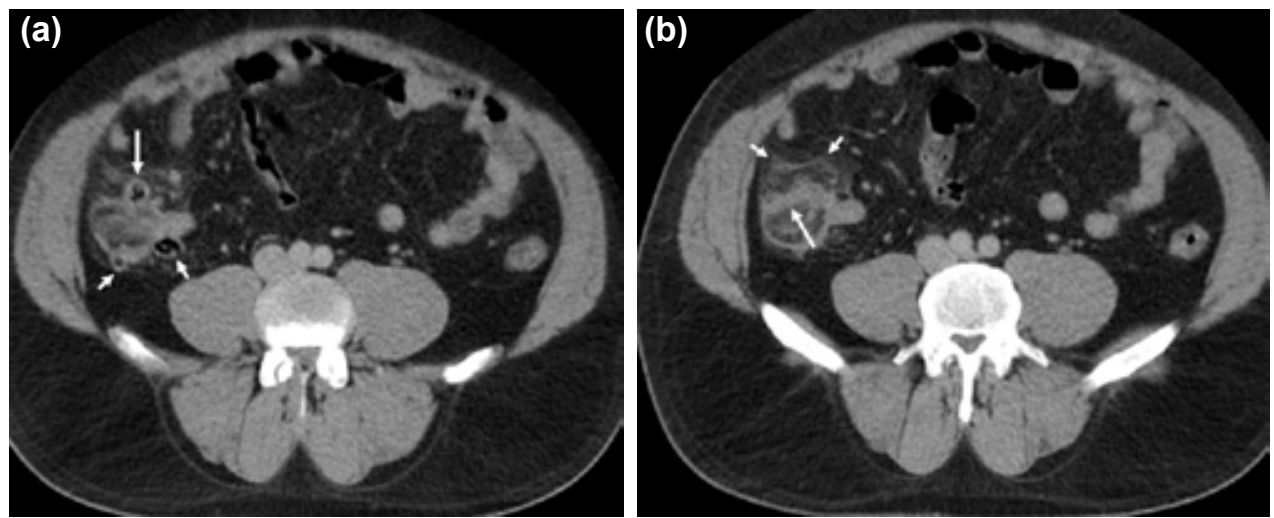

Figure 1. Cecal diverticulitis. Intravenous contrast-enhanced computed tomography examination revealed multiple diverticula at the level of the cecum ([a], small arrows) and thick-walled cecum ([a], long arrow). Segmental colonic wall thickening ([b], long arrow) and pericolic stranding ([b], small arrow) can also be seen. 
Table I. Presenting signs and symptoms

\begin{tabular}{lcc}
\hline Features & $\mathbf{n}$ & $\%$ \\
\hline Right lower quadrant pain & 8 & 72.7 \\
Leukocytosis & 8 & 66.6 \\
Pain for $>2$ days & 7 & 58.3 \\
Fever & 4 & 33.3 \\
Generalized abdominal pain & 4 & 33.3 \\
Nausea/vomiting & 2 & 16.6 \\
Diarrhea & 1 & 8.3 \\
\hline
\end{tabular}

Table 2. Computed tomography findings

\begin{tabular}{lcc}
\hline Criteria & n & $\%$ \\
\hline Colonic wall thickening and edema & II & 91.6 \\
Pericolonic fat infiltration & 9 & 75 \\
Pericolonic abscess & - & - \\
$\begin{array}{l}\text { Extraluminal air around the cecum or the } \\
\text { ascending colon }\end{array}$ & I & 8.3 \\
\hline
\end{tabular}

\section{DISCUSSION}

$\mathrm{RCD}$ is more common than left colonic diverticulitis in Asian populations; however, it is not commonly seen in Western countries. ${ }^{[9]}$ Number of cases identified as RCD with use of imaging techniques has been increasing in recent years. Studies have revealed that in the past, more than $70 \%$ of patients with cecal diverticulitis underwent surgery with preoperative diagnosis of acute appendicitis. ${ }^{[10]}$ Therefore, differentiation of RCD from acute appendicitis given similar physical examination findings prior to surgery should be regarded as most important point to prevent unnecessary diagnostic and therapeutic interventions.

Radiological evaluation should be performed for correct diagnosis and appropriate treatment of indeterminate right lower abdominal pain. US evaluation can be used as first modality in selected patients to evaluate right lower abdominal pain. [11,12] RCD should be considered if US findings show local wall thickening of the colon $(>4 \mathrm{~mm})$, regional pericolic fat thickening, oval-shaped or rounded hypoechoic or nearly anechoic structure protruding from segmentally thickened cecal or ascending colonic walls. ${ }^{[12]}$ Sensitivity of US for RCD has been reported in range of $78 \%$ to $96 \% .^{\left[{ }^{13]}\right.}$ In study conducted by Chou et al., abdominal US was shown to diagnose acute uncomplicated right colonic diverticulitis in 23 cases among 934 patients with indeterminate acute right lower abdominal pain. They demonstrated high sensitivity (91.3\%) and specificity $(99.8 \%)$ of US for diagnosis of RCD. ${ }^{[2]}$ Although US is one of the most cost-effective diagnostic modalities, it has some disadvantages, including variability, operator dependency, and difficulty in use with obese patients. ${ }^{[14,15]}$ Previous studies have reported several pitfalls and limitations that lowered diagnostic accuracy of US examinations, such as obesity and excessive bowel gas. It may be logical for very obese patients suspected of having RCD in differential diagnosis of right lower quadrant pain to be sent directly to $C T$ because of difficulty in penetrating tissue with US. ${ }^{[14,15]}$ However, US examinations should be primary imaging technique employed in young adults with normal body mass index and pregnant patients.

Diverticulitis is diagnosed more confidently with CT than abdominal US. ${ }^{[15]}$ CT scan has high sensitivity (93-97\%) and specificity (approximately 100\%) for diagnosis of diverticulitis. [16] CT scan may also be helpful to reveal other diseases responsible for lower right abdominal pain, such as acute appendicitis, ileitis, epiploic appendagitis, and inflammatory bowel disease. ${ }^{[17]}$ CT findings supportive of RCD include diverticula, regional colonic wall thickening, local pericolic inflammation, thickening of fascial planes, extraluminal air, extraluminal mass involving the cecum and/or ascending colon. ${ }^{[18-20]}$ Disadvantages of CT scanning are high cost, exposure to ionizing radiation and contrast. ${ }^{[14]}$ Our results indicated that majority of patients who were diagnosed with RCD using CT scan had pericolonic fat infiltration (75\%), or colonic wall thickening and edema (99.1\%). Although these imaging findings are common findings in several pathologies, such as inflammatory bowel disease or locally advanced colon cancer, presence of diverticula can be considered main pathognomonic criterion for RCD. Therefore, CT should be regarded as effective diagnostic modality for RCD due to presence of characteristic findings.

Treatment of RCD has typically been conservative according to studies published in recent years, contrary to studies in which surgical treatment, including diverticulectomy, wedge resection of the diverticulum, right hemicolectomy, and ileocecal resection were recommended or performed in most patients. ${ }^{[10,15,2]]}$ According to Puylaert's study, RCD has been shown to be common pathology seen for every 15 cases of sigmoid diverticulitis and 30 cases of appendicitis. It was also reported that $40 \%$ of RCD patients undergo right hemicolectomy due to presence of mass mimicking colonic tumor when operated on for diverticulitis. ${ }^{[15]}$ Fang et al. reviewed 67 patients who underwent laparotomy for cecal diverticulitis. Right hemicolectomy was performed in 34 (50.7\%) of 67 cases and diverticulectomy in 9 (13.4\%) cases. In that study, there were 2 deaths and 5 postoperative complications in right hemicolectomy group. Despite mortality and morbidity in the study group, they recommended aggressive surgical resection for patients with cecal diverticulitis. ${ }^{[22]}$ Some retrospective reports have shown low mortality rate (1.4\%) of right hemicolectomy for cecal diverticulitis. ${ }^{[23]}$ Therefore, it is logical to perform surgical treatment only if complications of diverticulitis occur or malignancy is strongly suspected based on clinical findings. ${ }^{[8,24,25]}$ 
Recurrence after conservative treatment of RCD has been reported in previous studies. In Komuta's study, failure of conservative management was $20.5 \%$ (16 of 80 patients with acute uncomplicated RCD). Interestingly, secondary and tertiary recurrences were seen in $81.25 \%$ (13 of 16) and $15.4 \%$ (2 of 13), respectively. Consequently, they concluded that conservative management rather than elective surgery should be considered for treatment for acute uncomplicated and recurrent RCD, despite these high recurrence rates. ${ }^{[14]}$ Park et al. published a study of 276 patients with RCD who were treated conservatively over mean follow-up period of 38 months and only 2 patients (1\%) developed recurrence. They concluded that if RCD tended to have benign progress, it should be managed conservatively. ${ }^{[6]}$ Yang et al. retrospectively reviewed cases of 87 patients with right colonic diverticulitis regarding response to conservative treatment (medical treatment alone or appendectomy with postoperative antibiotics) and reported recurrence rate of $12.5 \%$ over mean follow-up period of 37.5 months. They found that medical therapy can be safe and effective for both uncomplicated RCD and recurrent patients. Our study also demonstrated that recurrence was not found over short follow-up period ( $8.2 \pm 5.6$ months) and conservative treatment alone may be sufficient for uncomplicated RCD.

\section{Conclusion}

The present study has demonstrated that RCD is a self-limiting disease. If uncomplicated diverticulitis of the right colon is correctly diagnosed with radiological evaluation, conservative treatment with antibiotics and bowel rest should be considered for treatment. Colonic wall thickening, edema, and pericolonic fat infiltration have been observed in majority of patients diagnosed with RCD using CT. In-hospital observation was sufficient and there was no need for surgical intervention during hospital stay. In short-term follow-up, no recurrence was observed and conservative therapy offers advantage of avoiding surgery.

Conflict of interest: None declared.

\section{REFERENCES}

1. Sardi A, Gokli A, Singer JA. Diverticular disease of the cecum and ascending colon. A review of 881 cases. Am Surg 1987;53:41-5.

2. Jacobs DO. Clinical practice. Diverticulitis. $N$ Engl J Med 2007;357:2057-66. Crossret

3. Paramythiotis D, Papadopoulos VN, Michalopoulos A, Panagiotou D, Panidis S, Digkas E, et al. Inflammation of solitary caecal diverticula:a rare aetiology of acute abdominal pain [corrected]. Tech Coloproctol 2011;15 Suppl 1:43-5. Crossre

4. Mörschel M, Becker H. Diagnosis and therapy of cecal diverticulitis. [Article in German] Zentralbl Chir 1993;118:81-3. [Abstract]
5. Lehnert T, Kleikamp G. Diagnosis and therapy of inflammatory cecal diverticula. [Article in German] Zentralbl Chir 1989;114:1337-40. [Abstract]

6. Park HC, Chang MY, Lee BH. Nonoperative management of right colonic diverticulitis using radiologic evaluation. Colorectal Dis 2010;12:1058. Crossre

7. Lo CY, Chu KW. Acute diverticulitis of the right colon. Am J Surg 1996;171:244-6. Crossref

8. Hildebrand P, Kropp M, Stellmacher F, Roblick UJ, Bruch HP, Schwandner O. Surgery for right-sided colonic diverticulitis: results of a 10-yearobservation period. Langenbecks Arch Surg 2007;392:143-7. Crossre.

9. Issa N, Paran H, Yasin M, Neufeld D. Conservative treatment of rightsided colonic diverticulitis. Eur J Gastroenterol Hepatol 2012;24:12548. Crossret

10. Papapolychroniadis C, Kaimakis D, Fotiadis P, Karamanlis E, Stefopoulou M, Kouskouras K, et al. Perforated diverticulum of the caecum. A difficult preoperative diagnosis. Report of 2 cases and review of the literature. Tech Coloproctol 2004;8 Suppl 1:116-8. Crossre

11. Kang WM, Lee CH, Chou YH, Lin HJ, Lo HC, Hu SC, et al. A clinical evaluation of ultrasonography in the diagnosis of acute appendicitis. Surgery 1989;105:154-9.

12. Chou YH, Chiou HJ, Tiu CM, Chen JD, Hsu CC, Lee CH, et al. Sonography of acute right side colonic diverticulitis. Am J Surg 2001;181:122-7.

13. Hsu CC, Chou YH, Lai BH. Sonographic appearances of right-sided colonic diverticulitis. Journal of Medical Ultrasound 1996;4:180-3.

14. Komuta K, Yamanaka S, Okada K, Kamohara Y, Ueda T, Makimoto N, et al. Toward therapeutic guidelines for patients with acute right colonic diverticulitis. Am J Surg 2004;187:233-7. Crossree

15. Puylaert JB. Ultrasound of colon diverticulitis. Dig Dis 2012;30:56-9.

16. Jacobs DO. Clinical practice. Diverticulitis. N Engl J Med 2007;357:2057-66. Crossret

17. Rao PM. CT of diverticulitis and alternative conditions. Semin Ultrasound CT MR 1999;20:86-93. Crossret

18. Scatarige JC, Fishman EK, Crist DW, Cameron JL, Siegelman SS. Diverticulitis of the right colon: CT observations. AJR Am J Roentgenol 1987;148:737-9. Crossre

19. Crist DW, Fishman EK, Scatarige JC, Cameron JL. Acute diverticulitis of the cecum and ascending colon diagnosed by computed tomography. Surg Gynecol Obstet 1988;166:99-102.

20. Oudenhoven LF, Koumans RK, Puylaert JB. Right colonic diverticulitis: US and CT findings--new insights about frequency and natural history. Radiology 1998;208:611-8. Crossre

21. Lane JS, Sarkar R, Schmit PJ, Chandler CF, Thompson JE Jr. Surgical approach to cecal diverticulitis. Am Coll Surg 1999;188:629-35.

22. Fang JF, Chen RJ, Lin BC, Hsu YB, Kao JL, Chen MF. Aggressive resection is indicated for cecal diverticulitis. Am J Surg 2003;185:135-40.

23. Vajrabukka T, Saksornchai K, Jimakorn P. Diverticular disease of the colon in a far-eastern community. Dis Colon Rectum 1980;23:151-4.

24. Yang HR, Huang HH, Wang YC, Hsieh CH, Chung PK, Jeng LB, et al. Management of right colon diverticulitis: a 10-year experience. World J Surg 2006;30:1929-34. Crossree

25. Papaziogas B, Makris J, Koutelidakis I, Paraskevas G, Oikonomou B, Papadopoulos E, et al. Surgical management of cecal diverticulitis: is diverticulectomy enough? Int J Colorectal Dis 2005;20:24-7. Crossre] 
ORIJINAL ÇALIŞMA - ÖZET

\section{Radyolojik ve klinik bulgulara rağmen sağ kolon divertiküllerinin tanısında cerrahi gerekli mi?

\author{
Dr. Erkan Yardımcı, ${ }^{1}$ Dr. Mustafa Hasbahçeci, ${ }^{1}$ Dr. Ufuk Oğuz İdiz,, ${ }^{1}$ Dr. Musa Atay, ${ }^{2}$ Dr. Hüseyin Akbulut ${ }^{1}$
}

${ }^{1}$ Bezmialem Vakıf Üniversitesi Tıp Fakültesi, Genel Cerrahi Anabilim Dalı, İstanbul

${ }^{2}$ Bezmialem Vakıf Üniversitesi Tıp Fakültesi, Radyoloji Anabilim Dalı, İstanbul

AMAÇ: Batı toplumlarında sağ kolon divertikülleri nadir görülmektedir. Bu çalışmanın amacı bilgisayarlı tomografi ile tanısı konan sağ kolon divertiküllerinin konservatif tedavi ile sonuçlarını değerlendirmektir.

GEREÇ VE YÖNTEM: Şubat 2013 ile Aralık 2013 tarihleri arasında klinik ve radyolojik olarak sağ kolon ve çekal divertikülleri olan ve konservatif olarak tedavi edilen 12 hasta çalışmaya alındı. Demografik ve klinik veriler geriye dönük olarak değerlendirildi.

BULGULAR: Çalışmaya katılan kadın ve erkeklerin sayısı birbirine eşitti. Ortalama yaş 45.08 \pm I 4.4 yıl idi. Hastaların hastaneye başvurmadan önce geçen süre $2.08 \pm 1.3$ gün olup, en sık görülen semptom sağ alt kadran ağrısıydı (\%72.7). On hastaya sadece abdominal tomografi çekilirken, iki hastaya hem abdominal tomografi hem de abdominal ultrasonografi çekilmişti. Ortalama hastanede yatış süresi $2.8 \pm 1.5$ gün olup hastaların hepsi konservatif olarak tedavi edildi. Ortalama $8.2 \pm 5.6$ aylık takipte hiçbir hastada nüks gözlenmedi.

TARTIŞMA: Komplike olmayan sağ kolon divertikülleri radyolojik olarak tanımlanabilir, bağırsakların istirahati ile birlikte antibiyotik tedavisi düşük nüks olanları ile tedavi seçeneği olarak kullanılabileceği gibi sonraki dönemlerde cerrahi gerekebileceği akılda tutulmalıdır.

Anahtar sözcükler: Antibiyotik; bilgisayarlı tomografi; çekum, divertikülit; sağ kolon.

Ulus Travma Acil Cerrahi Derg 2017;23(I):6I-65 doi: 10.5505/tjtes.2016.51460 